\title{
Bullying behavior among students
}

\author{
Maria Ulfah, Erni Gustina \\ Faculty of Public Health, Universitas Ahmad Dahlan, Indonesia
}

\begin{tabular}{l} 
Article Info \\
\hline Article history: \\
Received Dec 10, 2019 \\
Revised May 4, 2020 \\
Accepted Jul 18, 2020 \\
\hline
\end{tabular}

\section{Keywords:}

Adolescent

Bullying

Peers' influence

School

Gender

\begin{abstract}
This study aimed to investigate whether communication patterns, peers' involvement and gender different can be the predictors of adolescent bullying behavior. This study involved 193 adolescents of grade 8 and 9 with the most adolescents of 14 years old who had filled in questionnaires. The results showed the prevalence of adolescent involvement in bullying which was $62.69 \%$. Parental communication patterns have an $\mathrm{OR}=1.64$ (95\% CI $=0.87-$ 3.09). Peers involvement in bullying behavior ( $\mathrm{OR}=1.92$; $95 \% \mathrm{CI}=1.01$ 3.66). Adolescent girls were more involved in bullying behavior $(59.59 \%)$ compared to adolescent boys $(\mathrm{OR}=3.32$; 95\% CI=1.69-6.54). Poor parental communication patterns, peers influence negatively predict to the bullying behavior in adolescent. Bullying is higher in boys than girls where as boys has a greater chance of bullying than girls. Therefore, bullying intervention programs are needed in schools.
\end{abstract}

This is an open access article under the CC BY-SA license.

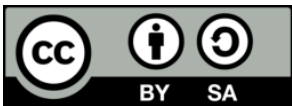

\section{Corresponding Author:}

Erni Gustina,

Faculty of Public Health,

Universitas Ahmad Dahlan,

Prof. Dr. Soepomo Street, Janturan, Yogyakarta (55164), Indonesia.

Email: erni.gustina@ikm.uad.ac.id

\section{INTRODUCTION}

Bullying [1-4] is defined as a subcategory of interpersonal aggression characterized by three criteria, namely intentionality, repetition, and imbalance of power with the aim of teasing, humiliating, hitting, social exclusion and isolating victim. With these characteristics, bullying is often defined as the systematic abuse of power by peers. This is recognized globally as a complex and serious problem. Abuse of power is the main difference between bullying and other forms of aggression and seriously affects the lives of some young children. Adolescents can be bullies, victims, and bully-victims [5].

Bullying is a serious public health problem due to the impact of bullying felt by both bullies and victims. Many studies on bullying have been carried out by various countries but the prevalence of bullying in each country is different. The prevalence of bullying is $48.5 \%$ in Ontorio [6], prevalence bullying in Australia was reported that $34 \%$ of boys had engaged in bullying behavior and 58\% of girls [7], in China was reported the incidences bullying, bullying others and witnessing bullying are $26.10 \%$ at elementary school, $9.03 \%$ at middle school and $28.90 \%$ at high and vocational [8]. The results of the study [9] stated that $25 \%$ claimed to be involved, $13 \%$ were victims of bullying, $8 \%$ were bullies, and $4 \%$ were bully-victims. Meanwhile in Indonesia it is reported that $49 \%$ of adolescents are victims of bullying [10].

Current thinking now reflects an understanding of bullying as a social and cultural phenomenon related to serious long-term consequences both physically and psychologically for bullies, victims, and bullyvictims [11]. bullying has been linked to anxiety [12], depression [10,13], bully-victims are at increased risk suicidality among young people, whereas risk of antisocial personality disorder for bullies [14]. Physical bullying is associated with suicide ideation and relational bullying was associated with suicide attempts [15]. 
Bullying victimization in adolescents is associated with poor social relationships, economic difficulties, and poor quality of life perceptions at the age of 50 years [16]. Bullying is also associated with poor academic performance, stressful school climate, and poor social relations in the school environment [17].

The school environment, peers, and family are important components in adolescent life [17]. The school is indicated as one of the spaces that allows violence and intimidation that is contrary to what is expected from the school context, namely as a space for socialization and protection [18]. Peer refusal, low parental monitoring, more time spent by teenagers outside the home were found to be associated with aggressive behavior [19]. While parental monitoring and awareness can provide greater protection for adolescents against the risk of online harassment [20]. Parental involvement in adolescent social relations such as parents know with whom their children socialize is predicted as a protective factor for adolescents not to be involved in victimization [21]. Conversely, poor quality adolescent attachment to parents and peers predicts bullying and victimization [22].

\section{RESEARCH METHOD}

This research used cross-sectional studies. Each class, which was consicted of 34 students grade 8-9, was divided into 6 sub-classes. Sample was taken randomly using inclusion criteria such as adolescents living with parents. Respondents were selected by proportional stratified random sampling where each sub-class was represented by 16 students with a total of 193 students. We adopted bullying behavior questionnaire and parental communication patterns from previous studies [23, 24]. Data analysis includes univariate analysis to describe the characteristics of each variable. Bivariate analysis was performed using the Chi square test to determine the relationship between the variables studied. Variables with p values less than 0.25 in the bivariate analysis were included in the multivariate analysis using logistic regression analysis.

\section{RESULTS AND DISCUSSION}

\subsection{Respondent characteristics}

This study involved 193 school teenagers. Of the 193 respondents, there were 38 boys $(48.72 \%)$ and 66 girls $(57.39 \%)$ who had 14 years of age as illustrated in Table 1.

Table 1. Characteristics respondent by aged of adolescent

\begin{tabular}{ccccc}
\hline \multirow{2}{*}{ Characteristics } & \multicolumn{2}{c}{ Boys $(\mathrm{n}=78)$} & \multicolumn{2}{c}{ Girls $(\mathrm{n}=115)$} \\
\hline Age & $\mathrm{n}$ & $\%$ & $\mathrm{n}$ & $\%$ \\
\hline 12 & 2 & 2.56 & 2 & 1.74 \\
13 & 29 & 37.18 & 44 & 38.26 \\
14 & 38 & 48.72 & 66 & 57.39 \\
15 & 7 & 8.87 & 3 & 2.61 \\
16 & 2 & 2.56 & 0 & 0.00 \\
\hline
\end{tabular}

\subsection{Frequency distribution of variables}

The results of univariate analysis in this study explain the frequency distribution of each study variable. $115(59.59 \%)$ were girls. The frequency distribution results in Table 2 shows that respondents who involved in bullying were 121 respondents $(62.69 \%)$. Respondents who have poor parental communication patterns are 105 respondents $(54.40 \%)$ and respondents who have friends who play a negative role are 94 respondents (40.41\%). Boys are more likely to involve in bullying behavior as presented in Table 3 .

Table 2. Distribution frequency bullies, parental communication patterns, peer's influences and gender

\begin{tabular}{cccc}
\hline Varibales & & Frequency $(\mathrm{n}=193)$ & Percentage (\%) \\
\hline Bullying behavior & Yes & 121 & 62.69 \\
& No & 72 & 37.31 \\
Parental communication patterns & Poor & 105 & 54.40 \\
& Good & 88 & 45.60 \\
\multirow{2}{*}{ Peers' influence } & Negative & 94 & 48.70 \\
& Positive & 99 & 51.30 \\
\multirow{2}{*}{ Gender } & Boys & 78 & 40.41 \\
& Girls & 115 & 59.59 \\
\hline
\end{tabular}


Table 3. Distribution frequency bullying behavior, parental communication patterns and peer's influences by gender

\begin{tabular}{cccccccc}
\hline \multirow{2}{*}{ Variables } & & \multicolumn{2}{c}{ Boys $(\mathrm{n}=78)$} & \multicolumn{2}{c}{ Girls $(\mathrm{n}=115)$} & \multicolumn{2}{c}{ Total } \\
& & $\mathrm{n}$ & $\%$ & $\mathrm{n}$ & $\%$ & $\mathrm{n}$ & $\%$ \\
\hline \multirow{2}{*}{ Bullying behavior } & Yes & 62 & 79.49 & 59 & 51.30 & 121 & 62.69 \\
& No & 16 & 20.51 & 56 & 48.70 & 72 & 37.31 \\
Parental communication patterns & Poor & 62 & 57.69 & 60 & 52.17 & 88 & 45.60 \\
& Good & 16 & 42.31 & 55 & 47.83 & 105 & 54.40 \\
Peers' influence & Negative & 47 & 60.26 & 47 & 40.87 & 94 & 48.70 \\
& Positive & 31 & 39.74 & 68 & 59.13 & 94 & 51.30 \\
\hline
\end{tabular}

\subsection{Bivariate analysis}

Bivariate analysis was conducted to determine the relationship between variables of communication patterns and the role of peers with bullying behavior. Chi square analysis showed relationship between parental communication patterns, peers' influence dan gender with bullying behavior (Table 4).

Table 4. Chi square analysis of bullying behavior and parental communication pattern, peers' influence and gender

\begin{tabular}{|c|c|c|c|c|c|}
\hline \multirow{2}{*}{ Variables } & & \multicolumn{2}{|c|}{ Bullying behavior } & \multirow{2}{*}{$\begin{array}{c}\text { Total } \\
\mathrm{N}\end{array}$} & \multirow{2}{*}{ P Value } \\
\hline & & Yes & No & & \\
\hline \multirow{2}{*}{ Parental communication patterns } & Poor & 73 & 32 & 105 & \multirow{2}{*}{0.032} \\
\hline & Good & 48 & 40 & 88 & \\
\hline \multirow{2}{*}{ Peers' influence } & Negative & 69 & 25 & 94 & \multirow{2}{*}{0.002} \\
\hline & Positif & 52 & 47 & 99 & \\
\hline \multirow{2}{*}{ Gender } & Boys & 62 & 16 & 78 & \multirow{2}{*}{0.0001} \\
\hline & Girls & 59 & 56 & 115 & \\
\hline
\end{tabular}

\subsection{Multivariate analysis}

This analysis was conducted to determine the predictors of bullying based on parental communication pattern, peers influence and gender. Poor parental communication between parents and youth have a 1.64 times chance to become a bullying compared to teens who have good communication patterns with parents but are not statistically significant. Adolescent who have friends with positive roles are likely to protect adolescents from bullying and are statistically significant $(\mathrm{OR}=1.92 ; 95 \% \mathrm{CI}=1.01-3.66)$. Adolescent boys had a risk of 3.32 times greater to carry out acts of bullying compared to adolescent girls and were statistically significant as illustrated in Table 5.

Table 5. Logistic regression of bullying behavior and parental communication pattern, peers influence and gender

\begin{tabular}{cccccc}
\hline \multirow{2}{*}{ Variables } & \multicolumn{2}{c}{$\begin{array}{c}\text { Bullying } \\
\text { behavior }\end{array}$} & Unadjusted & Adjusted OR \\
& & Yes & No & OR (95\%CI) & $(95 \% \mathrm{CI})$ \\
\hline \multirow{2}{*}{ Parental communication patterns } & Poor & 73 & 32 & $1.90 *$ & 1.64 \\
& Good & 48 & 40 & $(1.01-3.58)$ & $(0.87-3.09)$ \\
Peers' influence & Negative & 69 & 25 & $2.49 * *$ & $1.92^{*}$ \\
& Positif & 52 & 47 & $(1.31-4.79)$ & $(1.01-3.66)$ \\
Gender & Boys & 62 & 16 & $3.68 * * *$ & $3.32^{* *}$ \\
& Girls & 59 & 56 & $(1.83-7.62)$ & $(1.69-6.54)$ \\
\hline$*<0.05 ; * *<0.01 ; * * * 0.001 ;$ Pseudo R2 $=0.09$ & & & &
\end{tabular}

This study was conducted to identify the relationship between communication patterns of peer influence and adolescent gender with bullying behavior. Bullying can happen to anyone, both men and women. Teenage boys are more at risk of being bullied compared to adolescent girls. The percentage of male bullying behavior is greater than that of women where men are more at risk of becoming bullies $(12.1 \%$ in men and $4.8 \%$ in women) $[25,26]$. Boys are reportedly involved in bullying compared to teenage girls. Boys are significantly more likely to be bullies in school than girls [27]. Boys are more often involved in all types of intimidation incidents especially physical intimidation while young women are involved in verbal and emotional bullying [28]. In cases involving "talking about someone behind them"; in this situation, girls are more often involved as bullies than boys. As for victimization, boys are more directly physical victims than girls, while girls are more often the subject of dangerous gossip [29]. 
Teenagers who do bullying are due to many factors between socioeconomic factors, incomplete families such as single parents and children from broken home families. Some students claimed that their communication patterns with their parents were closed. Teenagers feel afraid to tell about problems experienced, often get harsh treatment from parents like being hit and often witnessing their parents fight. Meanwhile, their parents tend to be authoritarian, punitive and unsupportive and have less family cohesiveness which influences children to have bullying behavior [30, 31]. Student involvement with bullying is associated with aspects of family context and domestic violence [32].

Parents who often apply negative communication such as sarcasm, the child will get used to this attitude and tend to apply it in their social life. Children will also have a tendency towards bullying if parents do not provide affection and direction regarding positive attitudes [33]. Parental involvement [34] and high parental monitoring [35] provide a tendency to decrease adolescent involvement in bullying. Adolescents who have poor quality of attachment with parents and peers are reported predictors of bullying and victimization [22]. Parental support and poor supervision by fathers are found to be risk factors for adolescent boys to become bullies and victims [17].

Peers can have both positive and negative influences on adolescent behavior. Peer pressure is one of the causes of bullying behavior among adolescents in school, because adolescents, actively interact with their social environment as part of their identity development process. The results of this study indicate that peers who play a high negative role can lead to high bullying behavior at school. Adolescets want to behave in the same way as their peers so they think that bullying is normal and often witnesses their peers bullying. Peers who have a poor understanding of the effects of bullying can have a negative influence on adolescents [36]. Whereas good relationships with teachers, positive peer relationships and perceptions of academic achievement are protective factors [8]. Children who experience high peer rejection rates, internalization problems, and lower quality parent-child relationships contribute to persistent victimization [37].

Adolescents carry out bullying actions in order to get awards from friends and be accepted in the group. Peer have influence with bullying behavior where if peer influence is good then bullying behavior is low and if peer influence the less good peer then the bullying behavior that occurs is high [38]. Unhealthy peer relationships and a lack of support from the social environment will have a significant impact on the risk of bullying [39].

Bullying can be happened among children, adolescents and adults and has serious impact on health. The intervention program is needed to reduce bullying behavior. Mental health problems that arise early can pose a risk for experiencing psychiatric disorders in adulthood [40]. Prevention focuses not only on victims of bullying but also on perpetrators and bully-victims. Failure to prevent fundamental problems experienced by the three groups (bullies, victims of bullying, and bully-victims) can cause problems due to bullying [41]. Intervention for adolescent victims of bullying to reduce the risk of bullying by considering gender, type of bullying, and providing interpersonal support [15]. Parental involvement in monitoring children [20] and school involvement such as promoting a positive school environment, enhancing peer relationships at school, preventing and combating bullying is very important $[36,42]$.

\section{CONCLUSION}

Poor communication patterns between parents and adolescents can cause adolescents to become perpetrators of bullying. Adolescents who have friends with positive roles have opportunities as a protective factor against bullying. Male gender has a greater chance of bullying than female. The existence of bullying intervention programs can minimize the incidence of bullying in schools.

\section{REFERENCES}

[1] E. Menesini and C. Salmivalli, "Bullying in schools: the state of knowledge and effective interventions," Psychol. Heal. Med., vol. 22, no. S1, pp. 240-253, 2017.

[2] D. Olweus and S. P. Limber, "Bullying in school: Evaluation and dissemination of the olweus bullying prevention program," Am. J. Orthopsychiatry, vol. 80, no. 1, pp. 124-134, 2010.

[3] D. Olweus, Bullying at schools. What we know and what we can do. Wiley-Blackwell, Cambridge. Blackwell Publishing Ltd., Oxford OX4 1JF, UK, 1993.

[4] E. Englander, E. Donnersteins, R. Kowalski, C. A. Lin, and K. Parti, "Defining Cyberbullying," Pediatric, vol. 140, no. S2, pp. 221-229, 2019.

[5] D. Wolke and S. T. Lereya, "Long-term effects of bullying," Arch. Dis. Child., vol. 100, no. 9, pp. 879-885, 2015.

[6] N. Alavi, N. Roberts, C. Sutton, N. Axas, and L. Repetti, "Bullying victimization (Being Bullied) among adolescents referred for urgent psychiatric consultation: Prevalence and association with suicidality," Can. J. Psychiatry, vol. 60, no. 10, pp. 427-431, 2015.

[7] W. Crebbin, G. Campbell, D. A. Hillis, and D. A. Watters, "Prevalence of bullying, discrimination and sexual harassment in surgery in Australasia," ANZ J. Surg., vol. 85, no. 12, pp. 905-909, 2015. 
[8] Z. Han, G. Zhang, and H. Zhang, "School bullying in Urban China: Prevalence and correlation with school climate," Int. J. Environ. Res. Public Health, vol. 14, no. 10, pp. 1-13 2017.

[9] L. G. Durán, J. C. S. Schroh, E. P. Panizoni, E. F. Jouglard, M. G. Serralunga, and M. E. Esandi, "Bullying at school: Agreement between caregivers' and children's perception," Arch. Argent. Pediatr., vol. 115, no. 1, pp. 35-42, 2017.

[10] G. Marela, A. Wahab, and C. R. Marchira, "Verbal Bullying affects tennage depression of Yogyakarta senior high school students (in Bahasa)," Ber. Kedokt. Masy., vol. 33, no. 1, pp. 43-48, 2017.

[11] D. C. Rettew and S. Pawlowski, "Bullying," Child Adolesc. Psychiatr. Clin. N. Am., vol. 25, no. 2, pp. 235-242, 2016.

[12] L. Wichstrøm, J. Belsky, and T. S. Berg-Nielsen, "Preschool predictors of childhood anxiety disorders: A prospective community study," J. Child Psychol. Psychiatry Allied Discip., vol. 54, no. 12, pp. 1327-1336, 2013.

[13] E. Landstedt and S. Persson, "Bullying, cyberbullying, and mental health in young people," Scand. J. Public Health, vol. 42, no. 4, pp. 393-399, 2014.

[14] W. E. Copeland, D. Wolke, A. Angold, and E. J. Costello, "Adult Psychiatric and Suicide Outcomes of Bullying and Being Bullied by Peers in Childhood and Adolescence," JAMA Psychiatry, vol. 70, no. 4, pp. 419-426, 2013.

[15] S. Barzilay, et al., "Bullying Victimization and Suicide Ideation and Behavior among Adolescents in Europe: A 10-Country Study," J. Adolesc. Heal., vol. 61, no. 2, pp. 179-186, 2017.

[16] R. Takizawa, et al., "Adult health outcomes of childhood bullying victimization: Evidence from a five-decade longitudinal British birth cohort," Am. J. Psychiatry, vol. 171, no. 7, pp. 777-784, 2014.

[17] E. Erginoz, et al., "The role of parental, school, and peer factors in adolescent bullying involvement: Results from the Turkish HBSC 2005/2006 study," Asia-Pacific J. Public Heal., vol. 27, no. 2, pp. 1591-1603, 2015.

[18] M. A. I. Silva, et al., "The involvement of girls and boys with bullying: An analysis of gender differences," Int. J. Environ. Res. Public Health, vol. 10, no. 12, pp. 6820-6831, 2013.

[19] A. Borawski, Elaine, E. Ievers-Landis, Carolyn, D. Lovergreen, Loren, and S. Trapl, Erika, "Parental Monitoring, Negotiated Unsupervised Time, and Parental Trust: The Role of Perceived Parenting Practices in Adolescent Health Risk Behaviors," J Adolesc Heal., vol. 33, no. 2, pp. 60-70, 2003.

[20] A. Khurana, A. Bleakley, A. B. Jordan, and D. Romer, "The Protective Effects of Parental Monitoring and Internet Restriction on Adolescents' Risk of Online Harassment," J. Youth Adolesc., vol. 44, no. 5, pp. 1039-1047, 2015.

[21] P. Stavrinides, M. Nikiforou, and S. Georgiou, "Do mothers know? Longitudinal associations between parental knowledge, bullying, and victimization," J. Soc. Pers. Relat., vol. 32, no. 2, pp. 180-196, 2015.

[22] M. Nikiforou, S. N. Georgiou, and P. Stavrinides, "Attachment to Parents and Peers as a Parameter of Bullying and Victimization," J. Criminol., vol. 2013, Special Issue, pp. 1-9, 2013.

[23] A. Rohimah and Mamnu'ah, "The Relationship of the Role of Peer Groups with Behavior in School Age Children in SD Muhammadiyah Mlangi Gamping SLeman Yogyakarta," Aisyiyah, 2016.

[24] Megawati, "Relationship of Family Communication Patterns with Bullying Behavior in School Age Children at SD Muhammadiyah Mlangi Gamping Sleman Yogyakarta," Aisyiyah, 2015.

[25] Hermalinda, Deswita, and E. Oktarina, "The Relationship between Youth Characteristics and Bullying Behavior in Junior High School Students in Padang City," J. Keperawatan Soedirman, vol. 12, no. 1, pp. 1-11, 2017.

[26] A. K. Tsitsika, et al., "Bullying Behaviors in Children and Adolescents: An Ongoing Story," Front. Public Heal., vol. 2, no. 7, pp. 1-4, 2014.

[27] A. C. Baldry, D. P. Farrington, and A. Sorrentino, "School Bullying and Cyberbullying Among Boys and Girls: Roles and Overlap," J. Aggress. Maltreatment Trauma, vol. 26, no. 9, pp. 937-951, 2017.

[28] E. Gustina and M. Wibowo, "Sex, Friends and Bullying Among Adolescents," Int. J. Public Heal. Sci., vol. 4, no. 3, pp. 180-183, 2015.

[29] M. V. Carrera Fernández, M. L. Fernández, Y. R. Castro, J. M. Failde Garrido, and M. C. Otero, "Bullying in Spanish secondary schools: Gender-based differences," Span. J. Psychol., vol. 16, no. E21, pp. 1-14, 2013.

[30] P. K. Smith, Understanding school bullying: Its nature and prevention strategies, London: SAGE Publications Ltd., 2014.

[31] A. C. Baldry and D. P. Farrington, "Bullies and delinquents: Personal characteristics and parental styles," J. Community Appl. Soc. Psychol., vol. 10, no. 1, pp. 17-31, 2000.

[32] W. A. de Oliveira, J. L. da Silva, J. M. C. Sampaio, and M. A. I. Silva, "Students' health: an integrative review on family and bullying," Cienc. e Saude Coletiva, vol. 22, no. 5, pp. 1553-1564, 2017.

[33] I. Usman, "Personality, communication, peer groups, school climate and Bullying behaviour (in Bahasa)," Humanitas (Monterey. N. L)., vol. X, no. 1, pp. 49-59, 2013.

[34] H. Abdirahman, L. C. Fleming, and K. H. Jacobsen, "Parental involvement and bullying among middle school students in North Africa," East. Mediterr. Heal. J., vol. 19, no. 3, pp. 227-233, 2013.

[35] D. J. Meter and S. Bauman, "Moral Disengagement About Cyberbullying and Parental Monitoring: Effects on Traditional Bullying and Victimization via Cyberbullying Involvement," J. Early Adolesc., vol. 38, no. 3, pp. 303-326, 2018.

[36] R. Fataruba, "The Role of Peer Pressure on Bullying Behavior in Adolescents in Schools," in SEMINAR ASEAN 2nd Psychology \& Humanity Psychology Forum UMM, pp. 19-20, 2016.

[37] T. M. L. Kaufman, T. Kretschmer, G. Huitsing, and R. Veenstra, "Why Does a Universal Anti-Bullying Program Not Help All Children? Explaining Persistent Victimization During an Intervention," Prev. Sci., vol. 19, no. 6, pp. 822-832, 2018.

[38] Fithria and R. Auli, "Factors Related to Bullying Behavior," Idea Nurs. J., vol. VII, no. 3, pp. 9-17, 2016. 
[39] H. Huang, et al., "Understanding Factors Associated with Bullying and Peer Victimization in Chinese Schools Within Ecological Contexts," J. Child Fam. Stud., vol. 22, no. 7, pp. 881-892, 2013.

[40] R. Bannink, S. Broeren, P. M. Van De Looij-Jansen, F. G. De Waart, and H. Raat, "Cyber and traditional bullying victimization as a risk factor for mental health problems and suicidal ideation in adolescents," PLoS One, vol. 9, no. 4, pp. 11-16, 2014.

[41] M. Leiner, A. K. Dwivedi, M. T. Villanos, N. Singh, D. Blunk, and J. Peinado, "Psychosocial Profile of Bullies, Victims, and Bully-Victims: A Cross-Sectional Study," Front. Pediatr., vol. 2, no. 1, pp. 1-9, 2014.

[42] J. L. Silva, et al., "Anti-bullying interventions in schools: A systematic literature review," Cienc. e Saude Coletiva, vol. 22, no. 7, pp. 2329-2340, 2017. 